\title{
МЕТОДОЛОГИЯ ПОСТРОЕНИЯ ЗОНАЛЬНО-АДАПТИВНОЙ МАШИННОЙ ТЕХНОЛОГИИ ПРОИЗВОДСТВА ПЛОДОВ И ЯГОД С МИНИМАЛЬНЫМ АНТРОПОГЕННЫМ РИСКОМ ДЛЯ КАЧЕСТВА ПРОДУКЦИИ И ОКРУЖАЮЩЕЙ СРЕДЫ
}

\author{
А.Н. Перекопкий, канд. техн. наук, доцент \\ Контактная информация (e-mail): aperekopskii@,mail.ru \\ В.А. Юнин, канд. техн. наук \\ Контактная информация (e-mail): vim iaep@,mail.ru
}

А.В. Зыков

Контактная информация (e-mail): zav35@list.ru

К.И. Егорова, аспирант

Контактная информация (e-mail): unknown 06@list.ru

Институт агроинженерных и экологических проблем сельскохозяйственного производства филиал ФГБНУ ФНАЦ ВИМ (г. СПб, РФ)

ВВЕДЕНИЕ. Садоводство является одной из наиболее трудоемких отраслей сельского хозяйства, уровень механизации которой составляет порядка 15-20\%, что является основной сдерживающей причиной внедрения современных высокоэффективных технологий в производство плодово-ягодной продукции, вынужденного упрощения агротехнологий, снижения производительности труда и недобора урожая до 40-50 \%.

Зарубежный и отечественный передовой опыт показывает, что создание и подбор плодово-ягодных культур пригодных к машинной уборке урожая - одно из приоритетных направлений современных программ агрономов и селекционеров. Ещё недавно выращивание смородины сдерживалось из-за больших затрат ручного труда при сборе урожая. Учитывая это, становится очевидным актуальность анализа технических средств и сортов смородины чёрной пригодных для машинной уборки урожая.

Переход к передовым цифровым, интеллектуальным производственным технологиям и роботизированным системам предусмотрен "Стратегией научно технологического развития Российской Федерации", утвержденной Указом Президента РФ от 1 декабря 2016 г. № 642.

В Указе Президента России № 204 от 7 мая 2018 г. «О национальных целях и стратегических задачах развития Российской Федерации на период до 2024 года» задача преобразования приоритетных отраслей экономики и социальной сферы, включая сельское хозяйство, посредством внедрения цифровых технологий и платформенных решений, относится к числу главных приоритетов [1-3].

В связи с этим, создание методологии построения зонально-адаптивной машинной технологии производства плодов и ягод с минимальным антропогенным риском для качества продукции и окружающей среды является актуальной задачей.

В решении данных проблем развитие научных исследований сосредоточено в области рационального природопользования, технологий экологического развития и создания энергосберегающих систем использования энергии.

ОБЪЕКТ И МЕТОДИКА. Главным стратегическим планированием в создании местного производства продукции садоводства является разработка отечественных интенсивных технологий, адаптированных к конкретным климатическим и ресурсным условиям их реализации.

Садоводство Северо-Западного региона РФ занимает определённое место в производстве плодов и ягод с минимальным антропогенным риском («экологически чистой продукции») профилактического и лечебного назначения [4].

РЕЗУЛЬТАТЫ ИССЛЕДОВАНИЯ. Особенности климатических условий, в связи с географическим положением региона, обуславливают возможность использования природных ресурсов для производства такой продукции. Особенности климата выражаются в следующем: 
1. Высокий уровень влагообеспеченности региона определяет более высокую эффективность минеральных удобрений, чем в других зонах плодоводства, и возможность снижения доз внесения удобрений в почву;

2. Возможность применения дерново-перегнойной системы содержания почвы в многолетних насаждениях как средообразующего фактора, обеспечивающего регулирование азотного баланса в системе агроценоза растение-почва-растение, повышения плодородия почвы без внесения органических удобрений, улучшения товарных и пищевых качеств плодов и ягод;

3. Меньше, чем в других климатических зонах распространены в садах и ягодниках болезни и вредители, что позволяет снизить число обработок насаждений защитными средствами до 4-5 против 20 и более проводимых в садах средней и южной зонах;

4. В плодах и ягодах содержится витамина $\mathrm{C}$, Р-активных и других биологически активных веществ больше, чем в плодах, выращенных в южных регионах $[5,6]$.

Перечисленные особенности климатических условий создают потенциальную возможность снижения антропогенной нагрузки на агроценоз насаждения, на окружающую среду в целом.

Основой технологии, определяющей её экологичность, адаптивность и товарно-пищевые качества плодов и ягод являются:

1. Сорт - комплексный фактор продуктивности, адаптивности к почвенно-климатическим условиям, устойчивости к вредителям и болезням, качества плодов и ягод, приспособленности к машинному возделыванию;

2. Дерново-перегнойная система содержания почвы в насаждениях - средообразующий фактор многолетних насаждений [7];

3. Энергонасыщенная техника, включая технику сменно-модульного исполнения.

Взаимосвязь между факторами зонально-адаптивной безопасной машинной технологии производства плодов и ягод кустарниковых ягодников показана на рис. 1.

Промышленная технология производства ягод смородины чёрной апробирована на экспериментальной базе Ленинградской ПООС (ИАЭП - филиал ФНАЦ ВИМ) при полной механизации технологических процессов, а также исследованы последействия применения ягодоуборочной техники на состояние растений и их продуктивность. Применение отечественного самоходного комбайна МПЯ-1, а также комбайнов «Урсус» (Польша) и «Йонас-1000» (Финляндия) обеспечили высокий уровень товарности ягодной массы: полнота сбора составила 85$95 \%$ в зависимости от сорта и погодных условий в период уборки урожая, количество повреждённых ягод - не превышало 2 \%, собранная продукция - почти не содержала примеси листьев. Трудовые затраты складывались в среднем 50 чел.-час на 1 т. ягод. При выборе сорта для комбайновой уборки ягод важно учесть архитектонику куста, которая должна обеспечить максимальную реализацию продуктивного потенциала ветвей первой генерации в течение 35 лет, сохранение листьев после уборки урожая и хрупкость ветвей. Такие сорта смородины чёрной, как Фёдоровская (ЛПООС) и Лунная (СПбГАУ) в течение 3-4 сезонов машинной уборки сохраняли высокую урожайность. При предварительной оценке выделены сорта смородины чёрной различных НИИ: Петебурженка, Велой, Бинар, Искушение, Зелёная Дымка, Чёрный Жемчуг, сорт ЛПООС Марго, сорта крыжовника: Куйбышевский Чёрный, Малахит, Леденец, Аамисеппа, Маяк, сорта ЛПООС Краснославянский, Балтийский, Салют.

Для машинной технологии предпочтителен выбор энергонасыщенной техники блочномодульного исполнения. К такой технике относится отечественный высокоэффективный комбайн сменно-модульного типа КСМ-5. Всероссийским селекционно-технологическим институтом садоводства и питомниководства установлено, что из 11 перспективных марок технических средств, используемых при выполнении наиболее трудоёмких рабочих операций в ягодоводстве, 38 \% - отводится сменно-модульной технике на базе КСМ-5 [7]. 
ЭКОЛОГИЧНОСТЬ, АДАПТИВНОСТЬ, КАЧЕСТВО ПЛОДОВ, СНИЖЕНИЕ

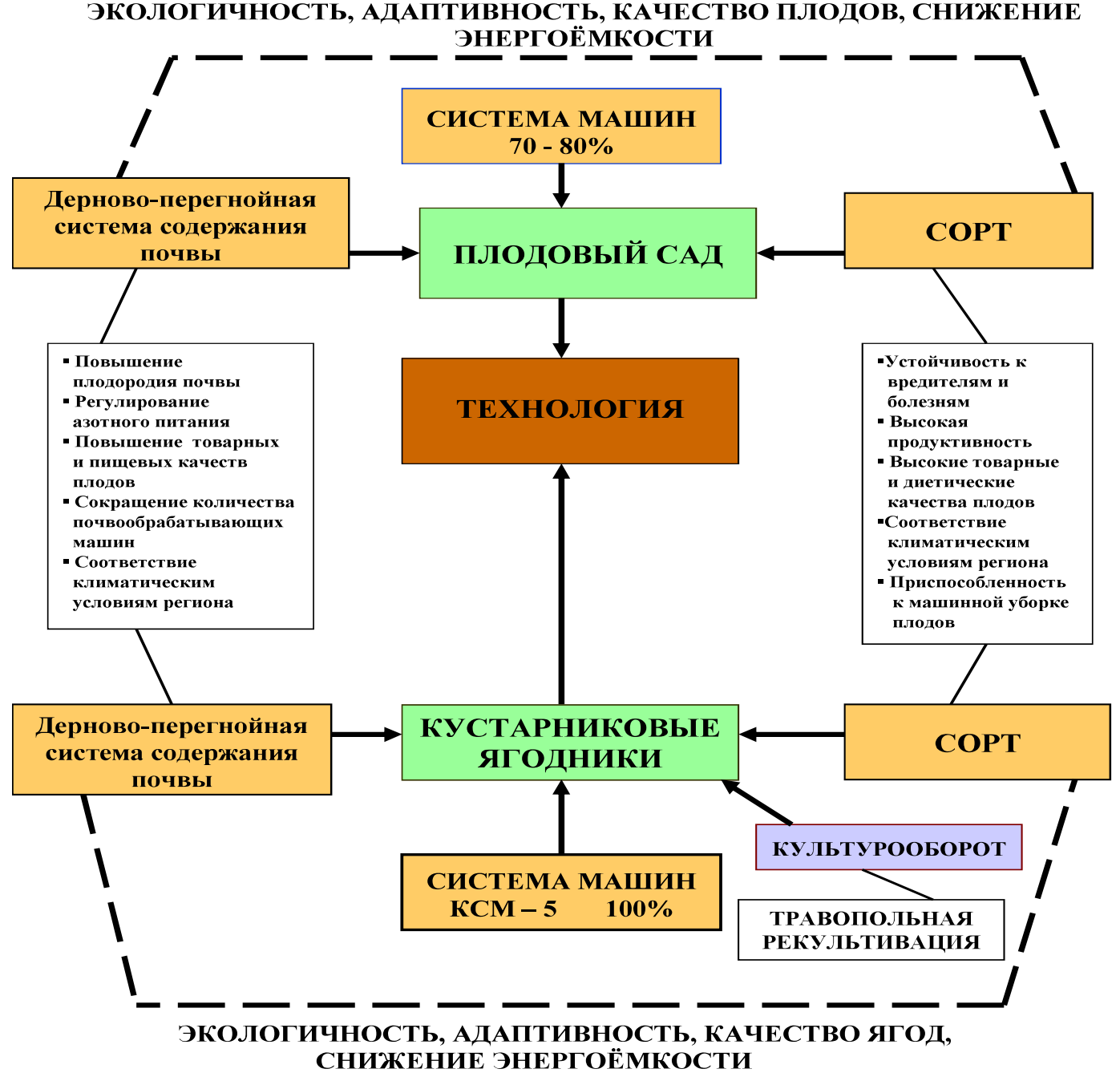

Рис. 1. Схема индустриальной технологии производства экологически «чистой» продукции (плодов и ягод)

В садах Северо-Западного региона промышленные технологии предназначены для главной культуры - яблони. К сортам предъявляется требование соответствия их интенсивному типу продуктивности. По пищевым качествам яблоки определяются как хорошие и отличные для профилактики заболеваний и лечения по показателю С/Р (содержание витаминов С и Р). На территории Северо-Запада культивируется группа сортов, плоды которых богаты витаминами - это сорта: Ренет Черненко, Теллисааре (C/P: 25-30/200-300), сорта Ленинградской плодоовощной опытной станции: Трудовое, Дружина, Ладога (C/P: 21-47/280-400). Количество ценных сортов может быть увеличено за счёт новых сортов, проходящих сортоиспытание в регионе.

Оценка дерново-перегнойной системы содержания почвы дана на основании исследований ряда лет в посадках смородины чёрной и многолетних многосторонних исследований в садах экспериментальной базы Ленинградской ПООС (ИАЭП - филиал ФНАЦ ВИМ) и внедрения в хозяйствах Северо-Западного региона.

Дерново-перегнойная система осуществляется путём постоянного задернения почвы многолетними низовыми злаковыми травами, периодически скашиваемыми (4-6 раз за вегетационный период) с оставлением их в измельчённом виде на месте.

Дерново-перегнойная система содержания почвы в садах и ягодниках рассматривается как эффективный способ удешевления производства продукции, в сочетании с возможностью формирования садоводства на принципах адаптивности и энергосбережения. К технологическим преимуществам дерново-перегнойной системы относятся: исключение внесения органических удобрений, сокращение набора машин по уходу за почвой; 5 технологических операций заменяются одной - скашивание травостоя; служит эффективным средством против смыва почвы. 
Многолетние травы улучшают водно-физические качества почвы, что вызывает изменение динамики формирования и повышения запаса продуктивной влаги в ней.

В почве, под многолетними травами, складывается бездефицитный режим азотного питания культуры. Основную роль в этом явлении играют обеспеченность почвы влагой и поступление в почву элементов питания из скошенной травы $[7,8]$.

Дерново-перегнойная система содержания почвы обеспечивает сочетание естественноприродных форм питания растений с применением минеральных удобрений в ограниченном количестве, которые используются растениями без накопления избытка азота в почве. Данная система приемлема как на почвах высокого бонитета (дерново-карбонатная), так и на условно садопригодных почвах (дерново-сильноподзолистая супесчаная на песчаных отложениях), в садах любой степени интенсивности их возделывания.

Постоянное задернение почвы относительно бедной подзолистой почвы оказывает более сильное влияние на повышение урожайности, чем задернение высокоокультуренной дерново-карбонатной почвы. Под влиянием трав создаются условия повышения товарности плодов за счёт уменьшения количества падалицы и поражения плодов паршой; плоды лучше вызревают, становится богаче их биохимический состав. Плоды, выращенные при задернении почвы, лучше сохраняются при длительном хранении, чем яблоки с чёрного пара.

В результате замены чёрного пара ведением дерново-перегнойной системы содержания почвы в многолетних насаждениях сокращаются затраты механизированного труда, стоимость амортизационных отчислений - на $25 \%$, доля стоимости сельхозмашин - на $61 \%$, удешевления стоимости материалов - на $71 \%$ в саду, на 55 \% - в ягодниках за счёт исключения применения органических удобрений.

ВЫВОДЫ. Представленная методология позволяет построить регионально-адаптивную экологически безопасную машинную технологию производства плодов и ягод с минимальным риском для качества продукции и окружающей среды. Поскольку для осуществления её имеются технические возможности, есть выгода для окружающей среды, так как технология содержит элементы органического садоводства.

\section{Литература}

1. Измайлов А.Ю., Смирнов И.Г., Хорт Д.О. Цифровые агротехнологии в системе «Умный сад»// Садоводство и виноградарство, 2018. № 6. - С. 33-39.

2. Смирнов И.Г. Разработка технологических процессов и технических средств для интеллектуальных технологий возделывания кустарниковых ягодных культур: Дисс. ... д-ра техн. наук. - М., 2019. - 427 с.

3. Труфляк Е.В., Курченко Н.Ю., Креймер А.С. и др. Мониторинг и прогнозирование научно-технологического развития АПК России на период до 2030 года. - Саратов, 2020. - 328 с.

4. Попов В.Д., Максимов Д.А., Морозов Ю.Л. и др. Технологическая модернизация отраслей растениеводства АПК Северо-Западного Федерального округа// СПб.: СЗНИИМЭСХ Россельхозакадемии, 2014. - 287 с.

5. Безух Е.П. Плодовый питомник Северо-Запада РФ. - СПб.: ИАЭП. 2020. - 442 с.

6. Краюшкина Н.С. Приоритеты развития садоводства Северо-Запада// Плодоводство и ягодоводство России, 2014. T. 38, №1. - C.222-228.

7. Краюшкина Н.С., Егорова К.И. Формирование сортимента смородины черной для регионально-адаптивной машинной технологии производства ягод// Технологии и технические средства механизированного производства продукции растениеводства и животноводства, 2018. № 3 (96). - С. 145-155.

8. Краюшкина Н.С., Нефедов В.В., Тюкалов Ю.А. Выбор машинной технологии производства ягод смородины черной в условиях северо-западного региона РФ// ГНУ СЗНИИМЭСХ Россельхозакадемии, 2014. № 85. - С 59-69. 